\title{
Rola otoczenia biznesu w rozwoju regionalnym w Polsce
}

\section{The role of the business environment in regional development in Poland}

\begin{abstract}
Streszczenie: We współczesnych przemianach systemu społeczno-gospodarczego ukształtowane środowisko działalności gospodarczej jest istotnym czynnikiem rozwoju. Wpływ otoczenia biznesu na rozwój regionu można analizować w wielu aspektach. Instytucje otoczenia biznesu mają wpływ na atrakcyjność inwestycyjną regionu, na poziom jego konkurencyjności. Przez relację innowacjaprzemysł przyczyniają się do rozwoju przemysłu wysokiej technologii, innowacyjności gospodarki regionu, a także do kształtowania się gospodarki opartej na wiedzy. Instytucje te także bezpośrednio wspierają działalność gospodarczą w szczególności małych i średnich przedsiębiorstw, świadcząc pomoc informacyjną, doradczą i szkoleniową (ośrodki szkoleniowo-doradcze), a także finansową (fundusze pożyczkowe i poręczeniowe) dla prowadzących działalność gospodarczą. Biorąc aktywny udział w sieciach powiązań sfery nauki i praktyki gospodarczej, umożliwiają kształtowanie się nowoczesnej gospodarki regionu. Celem artykułu jest analiza poziomu i dynamiki rozwoju otoczenia biznesu w latach 2000-2009 w ujęciu regionalnym oraz charakterystyka zależności między poziomem rozwoju otoczenia biznesu i poziomem rozwoju społeczno-gospodarczego regionów. W artykule podjęto próbę odpowiedzi na następujące pytania poznawcze: (1) które regiony Polski charakteryzują się najlepiej rozwiniętym otoczeniem biznesu, (2) jak kształtowała się dynamika rozwoju usług otoczenia biznesu w badanych regionach w latach 2000-2009 oraz (3) jak kształtuje się zależność między poziomem rozwoju otoczenia biznesu a poziomem rozwoju regionalnego.
\end{abstract}

Abstract: In the modern transformation of the socio-economic system, a shaped environment of the
economic activity is an important factor of development. The influence of business environment on
the development of a region can be analyzed in many ways. Business institutions have an impact on the
investment attractiveness of a region, and the level of its competitiveness. By the relation between inno-
vation and industry, they contribute to the development of high technology industries, innovativeness
in the region, and also the formation of a knowledge-based economy. These institutions also directly
support economic activities in small and medium-size enterprises in particular, providing information,
advisory and training (training and consultancy) as well as financial (loan and guarantee funds) support
for doing business. Taking an active part in the networks of relations of science and business practices
allow the formation of a modern regional economy.
The article aims to analyze the level and dynamics of development of the business environment in
$2000-2009$ in a regional context and the characteristics of the relationship between the level of devel- 
opment of business environment and the level of socio-economic development of regions. This article is an attempt to answer the following questions: (1) what the regional differentiation of business environment development in Poland is, (2) what the dynamics of business development in the regions in 2002-2009 was, and (3) what the relationship between level of development of business environment and regional level of socio-economic development is.

Słowa kluczowe: otoczenie biznesu, Polska, rozwój regionalny, środowisko innowacyjne

Keywords: business environment, innovative environment, Poland, regional development

\section{WPROWADZENIE}

Ukształtowane środowisko działalności gospodarczej jest istotnym czynnikiem rozwoju społeczno-gospodarczego. Otoczenie biznesu może być definiowane w wąskim lub szerokim zakresie. Według Z. Chojnickiego (1999: 368) pojęcie to w wąskim rozumieniu oznacza: „pewien klimat działalności gospodarczej przejawiający się w powstawaniu w regionie lub ośrodku miejskim warunków sprzyjających decyzjom lokowania i rozbudowy przedsiębiorstw", natomiast w szerokim znaczeniu obejmuje również wyposażenie instytucjonalne oraz otoczenie innowacyjne. W literaturze przedmiotu najczęściej wymienia się trzy główne składniki otoczenia biznesu: wyposażenie instytucjonalne, środowisko innowacyjne i właściwy klimat sprzyjający prowadzeniu działalności gospodarczej. Otoczenie biznesu należy do głównych czynników aktywizacji rozwoju regionu w trakcie współczesnych przemian gospodarczych w Polsce. Ukształtowane otoczenie biznesu z jednej strony jest czynnikiem lokalizacji działalności gospodarczej, a z drugiej strony warunkuje dynamiczny rozwój społeczno-gospodarczy. Celem artykułu jest analiza poziomu i dynamiki rozwoju otoczenia biznesu w latach 2002-2009 w ujęciu regionalnym oraz charakterystyka zależności między poziomem rozwoju otoczenia biznesu i poziomem rozwoju społeczno-gospodarczego regionów. W artykule podjęto próbę odpowiedzi na następujące pytania poznawcze: (1) które regiony Polski charakteryzują się najlepiej rozwiniętym otoczeniem biznesu, (2) jak przebiegała dynamika rozwoju usług otoczenia biznesu w badanych regionach w latach 2002-2009 oraz (3) jak kształtuje się zależność między poziomem rozwoju otoczenia biznesu a poziomem rozwoju regionalnego. Charakterystyka poziomu rozwoju otoczenia biznesu w regionach Polski obejmuje: wyposażenie instytucjonalne (w tym komercyjne usługi dla biznesu), środowisko innowacyjne oraz klimat sprzyjający działalności gospodarczej. Rezultatem tej analizy będzie klasyfikacja regionów na skali poziomu rozwoju otoczenia biznesu. Kolejny etap rozważań będzie dotyczył zależności pomiędzy otoczeniem biznesu a poziomem rozwoju społeczno-gospodarczego regionów.

Zakres czasowy analizy obejmuje lata 2002-2009. Wykorzystane dane statystyczne pochodzą z Banku Danych Lokalnych oraz z niepublikowanych materiałów Głównego Urzędu Statystycznego, a także z raportów Stowarzyszenia Organizatorów Ośrodków Innowacji i Przedsiębiorczości. 
ROLA OTOCZENIA BIZNESU W ROZWOJU SPOŁECZNO-GOSPODARCZYM REGIONÓW KONTEKST TEORETYCZNY

W świetle literatury przedmiotu pojęcie otoczenia biznesu obejmuje trzy główne składniki: wyposażenie instytucjonalne, otoczenie innowacyjne i klimat sprzyjający działalności gospodarczej ${ }^{1}$.

\section{WYPOSAŻENIE INSTYTUCJONALNE}

Wyposażenie instytucjonalne jest rozpatrywane dwojako: (1) jako zbiór instytucji otoczenia biznesu, (2) jako zbiór instytucji otoczenia biznesu wraz z ich wzajemnymi powiązaniami, które tworzą rodzaj sieci instytucjonalnej.

W pierwszym znaczeniu wyposażenie instytucjonalne ujmuje się jako tzw. usługi dla producentów i dla biznesu. A. Werwicki (1998), posługując się klasyfikacją usług przyjętą w brytyjskiej literaturze przedmiotu, odróżnia usługi dla producentów związane bezpośrednio z produkcją (usługi transportowe, bankowe, ubezpieczeniowe) od usług dla biznesu związanych z organizacją produkcji i zbytem produktów (usługi marketingowe, obsługa prawna, doradztwo finansowe). Wykazuje jednak, że podział ten nie jest rozłączny, dlatego usługi dla producentów i usługi dla biznesu ujmuje razem. Przedmiotem zainteresowania wielu badaczy otoczenia biznesu są wyłącznie usługi dla biznesu. Tego rodzaju podejście reprezentuje E. Nowosielska (2000: 11), która usługi dla biznesu utożsamia z grupą instytucji o charakterze komercyjnym, takich jak: działalność prawnicza, rachunkowość, księgowość, badanie rynku i opinii publicznej, doradztwo w zakresie prowadzenia interesów, zarządzanie i reklama. Usługi dla biznesu sklasyfikowane zostały w sekcjach: Pośrednictwo finansowe (J) PKD 2004 oraz Obsługa nieruchomości i firm, nauka (K) PKD 2004. Po zmianie obowiązującej klasyfikacji i przejściu na PKD 2007 w 2009 r. podmioty te zostały zaklasyfikowane do następujących sekcji: Informacja i komunikacja (J), Działalność finansowa i ubezpieczeniowa (K), działalność związana z obsługą rynku nieruchomości (L), Działalność profesjonalna, naukowa i techniczna $(\mathrm{M})$ oraz Działalność w zakresie usług administrowania i działalność wspierająca $(\mathrm{N})$.

W drugim znaczeniu wyposażenie instytucjonalne jest kategorią układu instytucjonalnego. Według J. Hausnera i innych (1997) układ ten jest uporządkowanym zbiorem instytucjonalnym uformowanym w skali regionu. Obejmuje zespół instytucji i organizacji, których zadaniem jest inicjowanie i sterowanie rozwojem regionu, wraz z występującymi między tymi instytucjami powiązaniami wewnętrznymi i zewnętrznymi. Układ instytucjonalny

\footnotetext{
${ }^{1} \mathrm{~W}$ ustalaniu składników otoczenia biznesu wykorzystano polską i zagraniczną literaturę z zakresu geografii społeczno-ekonomicznej i gospodarki przestrzennej. Na gruncie teorii organizacji i zarządzania wyróżnia się otoczenie bliższe i dalsze działalności gospodarczej (patrz: Penc-Pietrzak, 2002; Gierszewska, Romanowska, 1997; Obłój, 1998).
} 
tworzą: (1) agencje, fundacje i stowarzyszenia rozwoju regionalnego, (2) organizacje samorządu gospodarczego (izby gospodarcze), (3) organy terenowej administracji publicznej, (4) inne instytucje. Powiązania wewnętrzne i zewnętrzne instytucji otoczenia biznesu kształtują sieć instytucjonalną. C. Longhi (1999) instytucje otoczenia biznesu nazywa infrastrukturą instytucjonalną. Zalicza do niej: lokalny samorząd, izby handlowe, banki regionalne i centra usługowe. Podkreśla rolę tych instytucji w rozwijaniu więzi lokalnych między przedsiębiorstwami oraz w kształtowaniu współpracy na linii: przedsiębiorstwa-instytucje naukowe. D. Keeble i inni (1999), opisując wyposażenie instytucjonalne otoczenia biznesu, operują kategorią gęstości instytucjonalnej, którą definiują jako sieć połączonych i zintegrowanych organizacji i instytucji. Należą do nich: instytucje finansowe, izby handlowe, ośrodki szkoleniowe, stowarzyszenia handlowe, władze lokalne, agencje rozwoju, centra innowacji, agencje rządowe oraz organizacje świadczące usługi dla biznesu. Gęstość instytucjonalną kształtuje nie tylko zbiór instytucji otoczenia biznesu, ale także ich wzajemne powiązania i odpowiednia atmosfera do współpracy gospodarczej (por. Yoke-Tong Chew i Wai-Chung Yeung, 2001). Pojęcie gęstości instytucjonalnej stosuje również w polskiej literaturze I. Pietrzyk (2001).

\section{ŚRODOWISKO INNOWACYJNE}

Środowisko innowacyjne jest rozumiane trojako: (1) jako zbiór ośrodków innowacyjnych; (2) jako zbiór ośrodków innowacyjnych wraz ze skupiskami producentów dóbr i usług; (3) jako struktury sieciowe uwzględniające relacje wewnętrzne i powiązania zewnętrzne otoczenia innowacyjnego.

Instytucje działające w dziedzinie innowacji w Polsce określane są jako ośrodki innowacji i przedsiębiorczości (Jewtuchowicz, 1996; Matusiak, 1999; Mertl i Stawasz, 1996). Są to podmioty wyspecjalizowane w działaniach na rzecz rozwoju przedsiębiorczości, transferu technologii i komercjalizacji nowych technologii. Zalicza się do nich: (1) ośrodki szkoleniowo-doradcze - prowadzące działalność szkoleniową, doradczą i informacyjną, (2) centra transferu technologii - zajmujące się dyfuzją i komercjalizacją nowych technologii, odpowiedzialne za rozwijanie sieci kontaktów między nauką a gospodarką, (3) inkubatory przedsiębiorczości, centra technologiczne ${ }^{2}$, oferujące pomoc doradczą, techniczną i lokalową dla nowo powstających przedsiębiorstw w początkowym okresie ich funkcjonowania, (4) parki technologiczne - czyli zorganizowane kompleksy przemysłowe skupiające na określonym terenie instytucje naukowo-badawcze oraz otoczenie biznesu w zakresie finansowania, doradztwa i wspierania rozwoju firm innowacyjnych, (5) lokalne fundusze pożyczkowo-poręczeniowe - nienastawione na zysk jednostki parabankowe świadczące pomoc finansową w formie grantów i preferencyjnych pożyczek dla firm rozpoczynających działalność

${ }^{2}$ Polskie doświadczenia z centrami technologicznymi są bardzo skromne. W praktyce niewiele różnią się one od inkubatorów przedsiębiorczości (Matusiak, Zasiadły, 2001). 
gospodarczą oraz gwarancji i poręczeń dla małych rozwojowych firm, nieposiadających wymaganych zabezpieczeń kredytowych. Podstawową cechą ośrodków innowacji i przedsiębiorczości jest ich niekomercyjny charakter. Celem ich działalności nie jest maksymalizacja zysku, lecz wspieranie przedsiębiorczości oraz dyfuzja innowacji.

Środowisko innowacyjne, rozumiane jako zbiór ośrodków innowacyjnych wraz ze skupiskami producentów dóbr i usług określane jest w literaturze światowej przez P. Aydalota i D. Keeble'a, (1988) jako innovative milieu. Jest to lokalne skupisko firm zaawansowanej technologii (high-tech) oraz instytucji badawczo-rozwojowych (B+R), między którymi występują formalne i nieformalne powiązania. Powiązania te polegają na wymianie wysoko kwalifikowanych pracowników między firmami, uniwersytetami i jednostkami badawczo-rozwojowymi oraz na współpracy między producentami, dostawcami i odbiorcami.

Środowisko innowacyjne ujmowane jako sieć relacji jest zbiorem instytucji innowacyjnych, w którym wzajemna współpraca generuje dalszy rozwój innowacji i prowadzi do integracji środowiska innowacyjnego (por. Jewtuchowicz, 1996)

\section{KLIMAT SPRZYJAJĄCY DZIAŁALNOŚCI GOSPODARCZEJ}

Właściwy klimat sprzyjający działalności gospodarczej to czynnik rozwoju o charakterze miękkim, trudny do zmierzenia, w dodatku w badaniach empirycznych przyjmuje się różne jego definicje. Najczęściej mówi się o klimacie społecznym. Zdaniem J. Paryska (1997: 121): „właściwy klimat społeczny rozwoju lokalnego to taki stan warunków, w którym zasoby stają się aktywnymi czynnikami rozwoju, bowiem występują realne możliwości ich wykorzystania dla tego rozwoju". Do podstawowych elementów społecznego klimatu rozwoju lokalnego zalicza: 1) struktury społeczne szczebla lokalnego zainteresowane rozwojem lokalnym i popierające ten rozwój, 2) doświadczenie i wolę kreowania rozwoju przez samorząd terytorialny, 3) inicjatywę, aktywność i przedsiębiorczość mieszkańców, 4) prawne, organizacyjne, techniczne i technologiczne wspieranie inicjatyw, 5) materialno-finansowe wspomaganie inicjatyw rozwoju lokalnego i inne. Według G. Prawelskiej-Skrzypek i B. Domańskiego (1996: 151) analiza klimatu społecznego w aspekcie rozwoju przedsiębiorczości ekonomicznej pokazuje, że największą wagę mają czynniki regionalne o charakterze kulturowym, silne więzi społeczne, więzi z miejscem i regionem, duża aktywność społeczna i kultura przedsiębiorczości. Ich wpływ na rozwój regionu jest tak duży, że może skutecznie rekompensować niedostatki innych czynników.

\section{KLASYFIKACJA INSTYTUCJI I FIRM OTOCZENIA BIZNESU}

Na podstawie literatury charakteryzującej otoczenie biznesu i jego główne składniki na potrzeby analizy empirycznej przyjmuje się następującą klasyfikację instytucji i firm 
otoczenia biznesu: (1) wyposażenie instytucjonalne - obejmujące agencje, fundacje i stowarzyszenia działające na rzecz rozwoju regionalnego oraz organizacje gospodarcze; (2) usługi dla biznesu (firmy komercyjne świadczące usługi na rzecz biznesu - sekcje Pośrednictwo finansowe oraz Obsługa nieruchomości i firm PKD 2004³); (3) środowisko innowacyjne, tj. sfera działalności badawczo-rozwojowej $(\mathrm{B}+\mathrm{R})$ oraz instytucje odpowiedzialne na dyfuzję i transfer nowych technologii (ośrodki innowacji i przedsiębiorczości); (4) klimat społeczny - rozumiany jako przedsiębiorczość, zaangażowanie społeczności lokalnych na rzecz lokalnego i regionalnego rozwoju.

\section{ROLA OTOCZENIA BIZNESU W ROZWOJU SPOŁECZNO-GOSPODARCZYM REGIONÓW}

Według M. Hesselsa (1994) poziom rozwoju otoczenia biznesu (głównie usług dla producentów) jest symptomem rozwoju gospodarczego. Badania wpływu otoczenia biznesu na rozwój społeczno-gospodarczy były prowadzone w geografii światowej już w latach 80 . XX w. Do prac na ten temat należą: P. Pedersen (1986); A. Bailly i inni (1987); W. Gillis (1987); S. Illeris (1989); W.J. Coffey, M. Polese (1989); P.N. O’Farrell i D.M. Hitchens (1990); F. Martinelli (1991); M. Perry (1991). Otoczenie biznesu należy do głównych czynników aktywizacji rozwoju we współczesnych przemianach gospodarczych w Polsce. Znaczenie instytucji wzrasta $\mathrm{w}$ procesie rozwoju opartego na postfordowskim modelu organizacji produkcji (por. Stryjakiewicz, 1999; Chojnicki, 1993, 1999). Według J. Hausnera i innych (1997) instytucje otoczenia biznesu stymulują lokalną przedsiębiorczość, inicjują działalność innowacyjną i umożliwiają transfery nowoczesnych technologii. Poniżej przedstawiona została problematyka wpływu instytucji i firm otoczenia biznesu na rozwój społeczno-gospodarczy regionów w układzie wyróżnionych wcześniej składników.

Instytucje otoczenia biznesu wchodzące w skład wyposażenia instytucjonalnego odgrywają ważną rolę w rozwoju przedsiębiorczości regionu. Świadczą one usługi głównie dla rozpoczynających działalność małych i średnich przedsiębiorstw, a także dla funkcjonujących już firm. Małe przedsiębiorstwa nie mają warunków do tworzenia własnych jednostek badawczych, marketingowych itp. Instytucje otoczenia biznesu, takie jak: agencje, fundacje i stowarzyszenia rozwoju oraz organizacje gospodarcze, wspierają MŚP przez działalność informacyjną, szkoleniową i doradczą, stwarzając warunki sprzyjające powstawaniu nowych i funkcjonowaniu już istniejących małych i średnich przedsiębiorstw (Woodward, 1999; Yoke-Tong Chew i Wai-Chung Yeung, 2001). Dlatego w rozwoju małej przedsiębiorczości otoczenie biznesu ma istotne znaczenie. Szczególne wsparcie potrzebne jest tym przedsiębiorstwom, które zamierzają zastosować nowe technologie i wymagają wysoko wyspecjalizowanych usług. Dostęp do informacji, nowych technologii i innowacji zapewniany przez środowisko innowacyjne jest niezbędny do powstawania, funkcjonowania i rozwoju tych firm. Obecność właściwej infrastruktury instytucjonalnej związana jest także ze wzrostem

\footnotetext{
${ }^{3}$ W związku z ujęciem dynamicznym wykorzystano starszą wersję klasyfikacji PKD 2004.
} 
atrakcyjności regionu. Otoczenie biznesu stwarza warunki sprzyjające podejmowaniu decyzji lokalizacyjnych i rozwojowi przedsiębiorstw oraz wpływa na atrakcyjność inwestycyjną regionu. Instytucje otoczenia biznesu odgrywają istotną rolę w intensyfikowaniu działalności inwestycyjnej (por. Domański i in., 2000; Przybylska, 2001). Poziom rozwoju tych instytucji wykazuje związek ze zróżnicowaniem napływu zagranicznego kapitału inwestycyjnego w układzie regionalnym (Czyż, 1998). Instytucje otoczenia biznesu, zapewniające przedsiębiorstwom usługi finansowe, informacyjne, doradcze i szkoleniowe, wpływają korzystnie na atrakcyjność inwestycyjną regionu. Z tym także wiąże się rozwój przedsiębiorczości wpływający na wzrost zatrudnienia i utrzymanie równowagi na rynku pracy.

Nie mniejsza rola w rozwoju regionalnym przypada komercyjnym firmom świadczącym usługi dla biznesu. Współcześnie usługi tego typu stanowią najbardziej ekspansywną część sfery usług. Wskaźnikiem wzrostu znaczenia tego rodzaju usług w nowoczesnej gospodarce jest dynamika zatrudnienia i wzrost udziału w tworzeniu dochodu narodowego. Przyczyn wzrostu znaczenia usług dla biznesu upatruje się we wzroście złożoności i konkurencyjności nowoczesnej gospodarki. Wąska specjalizacja poszczególnych dziedzin gospodarki oraz konkurencja zmusza przedsiębiorców do korzystania z usług specjalistów z dziedzin: doradztwa podatkowego, rachunkowości, księgowości, badania rynku, reklamy, rekrutacji pracowników, prac badawczo-rozwojowych i innych (Daszkowska, 1998). Następuje eksternalizacja jednostek badawczo-rozwojowych z wielkich korporacji i przejmowanie ich przez firmy pośredniczące między nauką i gospodarką, specjalizujące się w opracowywaniu nowych technologii i sposobów ich wdrażania (Domański, 2000a).

Niezwykle istotny wpływ na rozwój regionów ma środowisko innowacyjne. Otoczenie biznesu przez dyfuzję innowacji ze sfery nauki do gospodarki wpływa na rozwój przemysłu wysokiej technologii i usług o wysokim nasyceniu wiedzą, przyczyniając się tym samym do rozwoju gospodarki opartej na wiedzy (Aydalot i Keeble, 1988; Dominiak, 2006). Instytucje środowiska innowacyjnego nie tylko prowadzą działalność innowacyjną, ale także zapewniają transfer nowych technologii z ośrodków naukowo-badawczych do przedsiębiorstw, ich komercjalizację i rozwój sieci kontaktów między nauką a gospodarką. Rezultatem działalności innowacyjnej w przedsiębiorstwach jest m.in. zastosowanie nowych technologii i rozwój nowoczesnego przemysłu. Bez dostępu do nowych technologii i informacji nowoczesny przemysł innowacyjny nie ma szans rozwoju. Działalność instytucji innowacyjnych stanowiących istotny składnik otoczenia biznesu jest koniecznym warunkiem rozwoju innowacyjnych przedsiębiorstw przemysłowych i ich sprawnego funkcjonowania. Działalność tego typu instytucji jest szczególnie istotna z punktu widzenia działalności małych i średnich firm, które nie dysponują odpowiednim zapleczem badawczym, a rozwój techniki i technologii, wzrastająca konkurencja zmusza je do wprowadzania innowacji (por. Jewtuchowicz, 1996). Rozwój regionów jest w dużej mierze uzależniony od rozwoju innowacyjności ich gospodarek. W dobie postępującej globalizacji gospodarki oraz przechodzenia do społeczeństwa informacyjnego rośnie znaczenie transferu informacji i technologii jako czynnika wzrostu konkurencyjności regionu (por. Kaluizhnova, Osipov, 2012). Tworzenie otoczenia 
ułatwiającego jednostkom gospodarczym uzyskanie przewagi konkurencyjnej jest ważnym zadaniem polityki regionalnej (por. Słodowa-Hełpa, 1998). Dzięki działalności tych instytucji wzrasta poziom rozwoju gospodarczego, poprawia się sytuacja finansowa regionu i ich mieszkańców.

Coraz większą rolę w rozwoju społeczno-gospodarczym regionów przypisuje się także tzw. miękkim, trudno mierzalnym czynnikom, takim, jak: przedsiębiorczość, kreatywność, silne więzi społeczne, więzi z miejscem i regionem, duża aktywność społeczna i kultura przedsiębiorczości, poświęcenie i zaangażowanie zarówno władz samorządowych, jak i ich mieszkańców, będące składnikami kapitału społecznego. Rozwój lokalny i regionalny jest ściśle powiązany z kapitałem ludzkim i społecznym - ważną rolę odgrywają tu relacje, wzajemna współpraca i powiązania. Istotnym aspektem wpływu otoczenia biznesu na rozwój regionów są właśnie ich wewnętrzne i zewnętrzne relacje. To dzięki wzajemnym powiązaniom oraz relacjom z gospodarką możliwy jest proces wspólnego uczenia się (collective learning - por. Bernardy, 1999; Keeble i Wilkinson, 1999; Keeble i in., 1999; Longhi 1999; Wolfe i Gertler, 2001). Według R. Domańskiego (2000b: 251):

uczenie się miast i regionów jest pochodną ich innowacyjności. Proces wspólnego uczenia się dokonuje się poprzez wzajemne oddziaływanie i współpracę firm, administracji rządowej i samorządowej, wyższych uczelni i instytutów badawczych, organizacji zawodowych, organizacji samorządu gospodarczego, instytucji społecznych.

Tworzenie wiedzy jest postrzegane jako podstawa zrównoważonego rozwoju ekonomicznego i tworzenia sprawnego regionalnego systemu innowacji (por. Keeble i Wilkinson, 1999; Longhi, 1999). Infrastruktura instytucjonalna odgrywa dużą rolę w kształtowaniu i zacieśnianiu więzi pomiędzy firmami oraz ułatwianiu współpracy między firmami i instytutami naukowymi, jednostkami badawczymi, uniwersytetami. Tworzy się swoisty system regionalny, oparty na współpracy i integracji podmiotów gospodarczych i różnorodnych instytucji, zapewniający nowe umiejętności i możliwości produkcji.

\section{ZRÓŻNICOWANIE PRZESTRZENNE POZIOMU ROZWOJU OTOCZENIA BIZNESU W POLSCE}

W analizie zróżnicowania przestrzennego poziomu rozwoju otoczenia biznesu w Polsce wykorzystano 15 cech diagnostycznych uporządkowanych w układzie składników otoczenia biznesu (tab. 1). Celowo wyłączono usługi dla biznesu wchodzące w skład wyposażenia instytucjonalnego i potraktowano je jako osobny składnik otoczenia biznesu ze względu na ich komercyjny charakter. 
Tab. 1. Wskaźniki poziomu rozwoju otoczenia biznesu

\begin{tabular}{|c|c|}
\hline Składniki otoczenia biznesu & Wskaźniki \\
\hline (1) Wyposażenie instytucjonalne & $\begin{array}{l}\text { 1.1. Organizacje prowadzące działalność wspomagającą rozwój } \\
\text { gospodarczy, w tym rozwój przedsiębiorczości (baza NGO) } \\
\text { na } 1 \text { tys. podmiotów gospodarczych } \\
\text { 1.2. Członkowie KIG na } 10 \text { tys. podmiotów gospodarczych }\end{array}$ \\
\hline (2) Usługi dla biznesu & $\begin{array}{l}\text { 2.1. Wskaźnik dynamiki zatrudnienia w usługach dla biznesu } \\
\text { 2000-2008 } \\
\text { 2.2. Odsetek pracujących w usługach informatycznych } \\
\text { 2.3. Odsetek pracujących w usługach finansowych } \\
\text { i ubezpieczeniowych } \\
\text { 2.4. Odsetek pracujących w obsłudze prawnej, księgowej, } \\
\text { doradztwie, reklamie i pozostałej działalności profesjonalnej }\end{array}$ \\
\hline (3) Środowisko innowacyjne & $\begin{array}{l}\text { 3.1. Liczba jednostek sfery } \mathrm{B}+\mathrm{R} \\
\text { 3.2. Udział zatrudnienia w działalności } \mathrm{B}+\mathrm{R} \text { w zatrudnieniu } \\
\text { krajowym } \\
\text { 3.3. Liczba pracowników naukowo-badawczych na } 1 \text { tys. osób } \\
\text { aktywnych zawodowo } \\
\text { 3.4. Nakłady na działalność badawczo-rozwojową w relacji do } \\
\text { PKB (GERD) } \\
\text { 3.5. Liczba ośrodków innowacji i przedsiębiorczości }\end{array}$ \\
\hline (4) Klimat społeczny & $\begin{array}{l}\text { 4.1. Organizacje wspomagające rozwój techniki, wynalazczości } \\
\text { i innowacyjności, rozpowszechnianie i wdrażanie nowych } \\
\text { rozwiązań technicznych w gospodarce (baza NGO) na } \\
10 \text { tys. podmiotów gospodarczych } \\
\text { 4.2. Jednostki nowo zarejestrowane w rejestrze REGON } \\
\text { na } 10 \text { tys. ludności } \\
\text { 4.3. Udział aktywnych zawodowo } \\
\text { 4.4. Organizacje działające na rzecz rozwoju wspólnot } \\
\text { i społeczności lokalnych (baza NGO) na } 1 \text { tys. podmiotów } \\
\text { gospodarczych }\end{array}$ \\
\hline
\end{tabular}

Źródło: opracowanie własne

W analizie zróżnicowania przestrzennego poziomu rozwoju otoczenia biznesu zastosowano syntetyczny wskaźnik Perkala ${ }^{4}$ w następującej postaci (Runge, 2007: 214):

$$
W_{s}=\frac{\sum_{j=1}^{p} y_{i j}}{p}
$$

gdzie:

$W_{s}$ - wskaźnik syntetyczny

$j-1,2, \ldots, \mathrm{p}$

$p$ - liczba uwzględnionych cech

$y_{i j}$-standaryzowana wartość $j$-tej cechy dla $i$-tego obiektu.

${ }^{4}$ Wskaźnik Perkala do oceny potencjału innowacyjnego województw wykorzystali m.in. A. Nowakowska, M. Feltynowski (2009: 11-24). 
Zastosowanie wskaźnika syntetycznego wymagało w pierwszej kolejności standaryzacji wartości wskaźników opisujących natężenie poszczególnych cech. Standaryzację dla cech mających charakter stymulant przeprowadzono z wykorzystaniem formuły:

$$
y_{i j}=\frac{x_{i j}-\bar{x}}{S_{j}}
$$

gdzie:

$y_{i j}$ - standaryzowana wartość $j$-tej cechy dla $i$-tego obiektu

$x_{i j}$ - wartość $j$-tej cechy dla $i$-tego obiektu

$\bar{x}$ - średnia arytmetyczna wartości $j$-tej cechy

$S_{j}$ - odchylenie standardowe wartości $j$-tej cechy

Standaryzacja wartości wskaźników doprowadziła do uzyskania macierzy zmiennych standaryzowanych, które wykorzystano przy obliczaniu wskaźników syntetycznych $\left(\mathrm{W}_{\mathrm{S}}\right)$ dla 2009 r. Na podstawie rozpiętości wartości wskaźników syntetycznych określono skalę zróżnicowania występującego w poziomie rozwoju otoczenia biznesu w województwach w Polsce. Wyniki analizy przestawia ryc. 1.

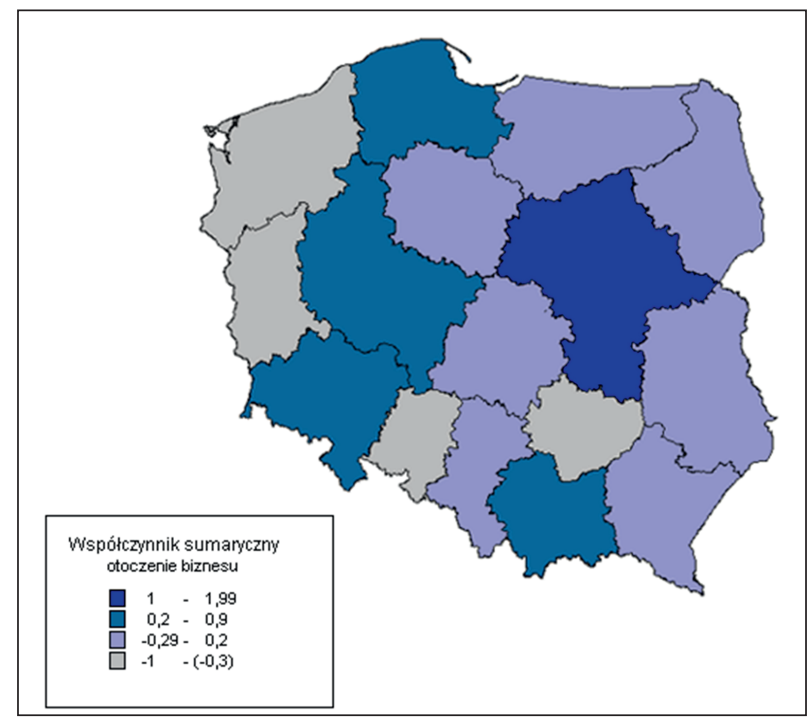

Ryc. 1. Zróżnicowanie regionalne otoczenia biznesu w Polsce w 2009 r.

Źródło: opracowanie własne

W analizie zróżnicowania przestrzennego poziomu rozwoju otoczenia biznesu w Polsce zastosowano wskaźnik sumaryczny poziomu rozwoju otoczenia biznesu (WS) oraz wskaźniki cząstkowe (WC1, WC2, WC3, WC4) odpowiadające czterem wyróżnionym składnikom otoczenia biznesu: wyposażeniu instytucjonalnemu, usługom dla biznesu, środowisku innowacyjnemu oraz klimatowi sprzyjającemu działalności gospodarczej. W klasyfikacji 
województw na podstawie sumarycznego wskaźnika poziomu rozwoju otoczenia biznesu zdecydowanym liderem jest województwo mazowieckie. Tylko w jego przypadku wartość wskaźnika Perkala oscylowała wokół 2. Dla drugiego w zestawieniu - województwa małopolskiego - wartość wskaźnika wynosiła jedynie 0,36. Drugą klasę (ponadprzeciętny rozwój otoczenia biznesu) stanowiły województwa charakteryzujące się relatywnie wysokim poziomem rozwoju społeczno-gospodarczego: małopolskie, dolnośląskie, pomorskie i wielkopolskie. W skład trzeciej klasy (przeciętny poziom rozwoju otoczenia biznesu) weszły województwa: łódzkie, śląskie, podlaskie, podkarpackie, warmińsko-mazurskie, a ostatnią czwarta klasę stanowią województwa o najsłabszym poziomie rozwoju otoczenia biznesu: zachodniopomorskie, lubuskie, opolskie, świętokrzyskie.

Analiza zróżnicowania regionalnego poszczególnych składników otoczenia biznesu w Polsce pokazała, że podobnie jak w przypadku ujęcia całościowego województwo mazowieckie zdecydowanie wyróżnia się w przypadku wszystkich czterech analizowanych składników otoczenia biznesu. Zaobserwowano jednak dużą rozbieżność między rozkładami pozostałych województw w ujęciach częściowych WC1, WC2, WC3 i WC4. Pierwszy analizowany składnik otoczenia biznesu: wyposażenie instytucjonalne (WC1) - poza województwem mazowieckim - najlepiej rozwinięte jest w województwach wschodniej części Polski. Na mapie widać niemal idealny rozkład województw w układzie Polska wschodnia - środkowa - zachodnia. Taki stan tłumaczy się najczęściej faktem, że instytucje wchodzące w skład wyposażenia instytucjonalnego, a więc najczęściej agencje, stowarzyszenia rozwoju często tworzone są odgórnie właśnie na terenach charakteryzujących się słabym rozwojem gospodarczym.

Kolejny składnik - usługi dla biznesu - a więc komercyjne firmy świadczące usługi przede wszystkim dla prowadzących działalność gospodarczą, cechuje się już rozkładem skorelowanym z ogólnym poziomem rozwoju społeczno-gospodarczego. Zaraz po województwie mazowieckim uplasowały się województwa: dolnośląskie małopolskie i pomorskie. Najsłabiej usługi dla biznesu rozwinęły się w województwach: lubuskim, warmińsko-mazurskim, opolskim, świętokrzyskim, podkarpackim oraz lubelskim (ryc. 2).

W przypadku usług dla biznesu ze względu na dostępność danych statystycznych możliwa była jeszcze dokładniejsza analiza ich rozmieszczenia na poziomie NUTS4 (powiaty). Na podstawie analizy skupień przeprowadzonej na wskaźniku Perkala dokonano klasyfikacji jednostek w układzie NUTS4 na trzy skupienia 5 . W skład skupienia I identyfikowanego jako obszary wysokiego poziomu rozwoju w aspekcie danego składnika wchodzą przede wszystkim miasta wojewódzkie i miasta na prawach powiatów. Z mapy zróżnicowania usług dla biznesu w układzie NUTS4 wynika również jasno, że dominacja Mazowsza wynika jedynie ze stołecznego charakteru Warszawy, gdzie lokalizowane są główne siedziby

${ }^{5} \mathrm{~W}$ analizie skupień realizowanej za pomocą metody $k$-średnich otrzymuje się dokładnie $k$ skupień, które charakteryzują się maksymalną odmiennością. Algorytm rozpoczyna się od $k$ losowych skupień, a następnie obiekty są przenoszone między tymi skupieniami, zmierzając do: (1) minimalizacji zmienności wewnątrz skupień, (2) maksymalizacji zmienności między skupieniami. W grupowaniu metodą $k$-średnich w algorytmie zakłada, że obiekty (np. przypadki) przenoszone są do i z grup (skupień), tak aby otrzymać najbardziej istotne wyniki analizy (Hand i in., 2005). Przeprowadzona analiza badanych jednostek miała na celu wyznaczenie trzech skupień (regiony o wysokim, przeciętnym i niskim poziomie rozwoju otoczenia biznesu). 
banków, towarzystw ubezpieczeniowych, krajowych organizacji gospodarczych, agencji rozwoju oraz największe instytuty badawcze. Pozostała część województwa mazowieckiego charakteryzuje się znacznie niższym poziomem rozwoju usług dla biznesu. Usługi dla biznesu to rodzaj wyspecjalizowanych usług wymagających często wysokich i wyspecjalizowanych kwalifikacji, dlatego też najczęściej są usługami wielkomiejskimi. Analiza w tym układzie wyraźnie pokazuje, że podobna sytuacja ma miejsce w innych miastach wojewódzkich, a wielkość miasta wojewódzkiego ma decydujące znaczenie dla miejsca zajmowanego w klasyfikacji województw. Z mapy wynika także, że w Polsce nie obserwuje się jeszcze tak jak ma to miejsce m.in. w innych państwach Europy Zachodniej i Stanów Zjednoczonych - lokalizowania na znaczącą skalę usług dla biznesu w strefach podmiejskich dużych miast. Powiaty ziemskie wokół Poznania, Trójmiasta, Krakowa czy nawet Warszawy nie wyróżniają się znacząco liczbą zatrudnionych w usługach dla biznesu.
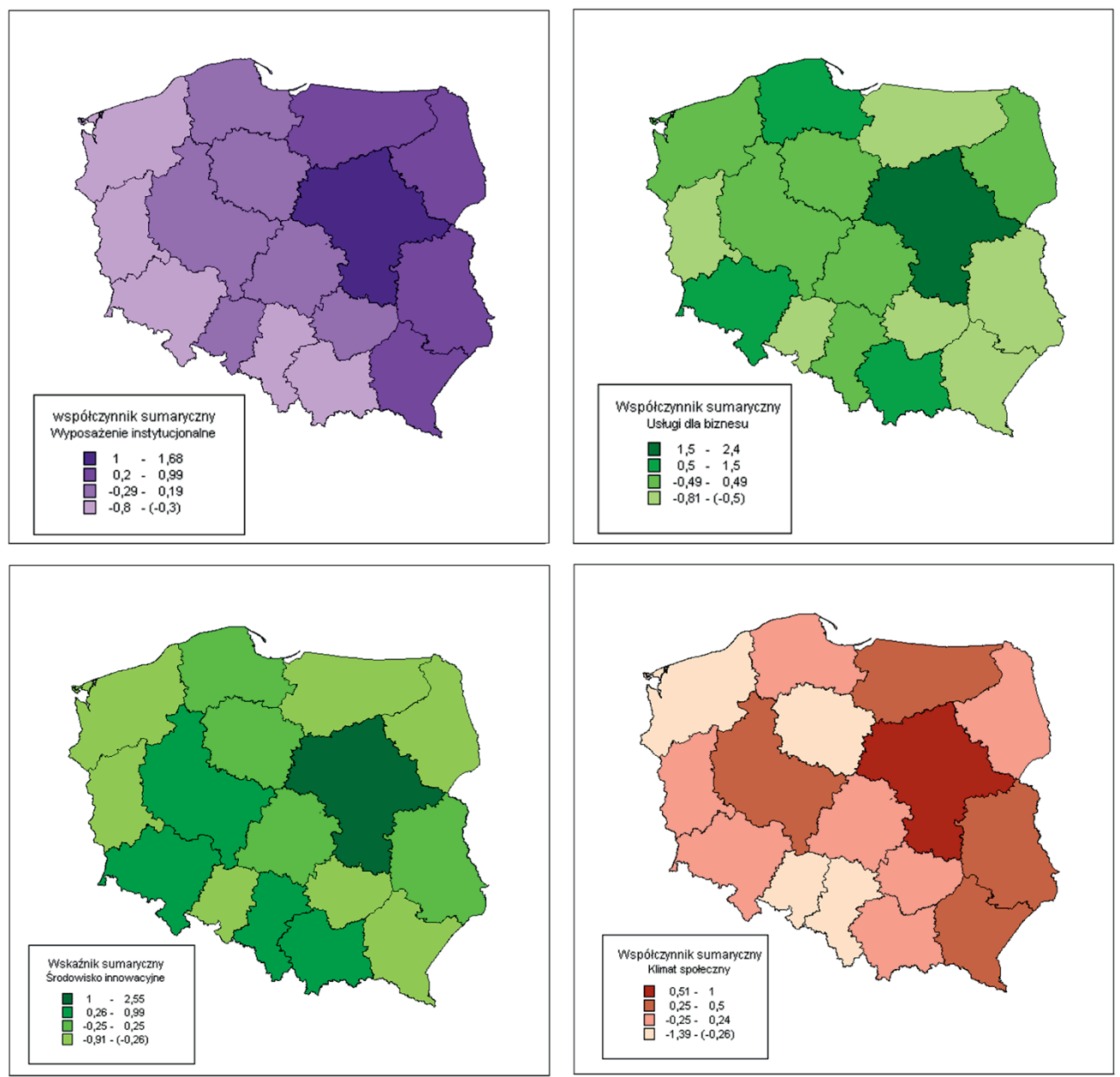

Ryc. 2. Regionalne zróżnicowanie składników otoczenia biznesu w Polsce w 2009 r.

Źródło: Opracowanie własne 
Trzeci analizowany składnik otoczenia biznesu - środowisko innowacyjne - charakteryzuje się podobnym rozkładem do poprzedniego. Poza województwem mazowieckim województwami charakteryzującymi się najwyższym poziomem rozwoju środowiska innowacyjnego są: dolnośląskie, małopolskie, śląskie i wielkopolskie.

Zupełnie odmienna jest sytuacja w przypadku czwartego składnika otoczenia biznesu - klimatu społecznego. Nie zachodzi dodatnia silna korelacja z poziomem rozwoju społeczno-gospodarczego. Do klasy województw cechujących się ponadprzeciętnymi wartościami wskaźnika zaliczono zarówno województwa silne gospodarczo - wielkopolskie, jak i zdecydowanie słabsze - warmińsko-mazurskie, podkarpackie i lubelskie.

\section{Dynamika Rozwoju otoczenia BIZNesu w Polsce}

Ujęcie dynamiczne rozwoju otoczenia biznesu w Polsce w układzie wyżej analizowanych cech nie jest możliwe ze względu na brak dostępu do danych statystycznych. Dlatego w tej części opracowania wykorzystano zredukowany zestaw cech przedstawiający się następująco. W zakresie usług dla biznesu: (1) odsetek pracujących w usługach informatycznych w 2002 r., (2) odsetek pracujących w usługach finansowych ubezpieczeniowych w 2002 r., (3) odsetek pracujących w obsłudze prawnej, księgowej, doradztwie, reklamie i pozostałej działalności profesjonalnej w 2002 r. W zakresie środowiska innowacyjnego: (1) liczba jednostek sfery B+R w 2002 r., (2) udział zatrudnienia w działalności B+R w zatrudnieniu krajowym w 2002 r., (3) liczba pracowników naukowo-badawczych na tys. osób aktywnych zawodowo w 2002 r., (4) nakłady na działalność badawczo-rozwojową w relacji do PKB (GERD) w 2002 r., (5) liczba ośrodków innowacji i przedsiębiorczości w 2001 r. W zakresie klimatu społecznego: (1) jednostki nowo zarejestrowane w rejestrze REGON na 10 tys. ludności w 2000 r. i (2) udział aktywnych zawodowo w 2002 r.

W obu analizowanych latach zdecydowanie wyróżniało się województwo mazowieckie. Jego przewaga nad pozostałymi województwami była wysoka, wskaźnik Perkala tylko dla Mazowsza oscylował wokół wartości 2. Na drugim miejscu, ze znaczną stratą do Mazowsza, w obu zestawieniach znalazło się województwo małopolskie. W 2009 r. w porównaniu z 2002 r. wartość wskaźnika Perkala nieco spadła, ale należy zwrócić uwagę, że do analizy został przyjęty nieco inny zestaw cech (ze względu na dostępność danych). Z analizowanego zestawienia wynika, że z grupy województw o ponadprzeciętnych wartościach przyjętego wskaźnika poziomu rozwoju otoczenia biznesu w 2009 r. znikło województwo łódzkie. W 2009 r. wartość wskaźnika Perkala dla łódzkiego była ujemna i wyniosła -0,05. Pozostałe województwa w tej grupie: małopolskie, dolnośląskie, pomorskie i wielkopolskie, nie zmieniły swoich pozycji. Znaczące zmiany nastąpiły natomiast w klasie województw charakteryzujących się przeciętnym poziomem rozwoju otoczenia biznesu. W 2002 r. zaliczono do niej jedynie trzy województwa: śląskie, lubelskie i zachodniopomorskie. W 2009 r. w tej grupie nadal utrzymały się województwa śląskie i lubelskie, natomiast zachodniopomorskie spadło do grupy województw o niskim poziomie rozwoju otoczenia biznesu. Dodatkowo 
w klasie III znalazło się województwo łódzkie (które spadło z klasy II) oraz trzy województwa, które awansowały z klasy IV: warmińsko-mazurskie, podlaskie, podkarpackie. W klasie czwartej pozostały: kujawsko-pomorskie, świętokrzyskie, lubuskie, opolskie oraz zachodniopomorskie, które spadło z klasy III. Ogólnie zaznacza się tendencja do wyrównywania różnic w poziomie rozwoju otoczenia biznesu - w latach 2002-2009 nastąpiło upodobnienie wartości wskaźnika. Tendencja ta dotyczy przede wszystkim województw o przeciętnym poziomie rozwoju otoczenia biznesu. Obserwuje się także wzrost wartości wskaźnika Perkala dla wszystkich województw z klasy IV.

Tab. 2. Zmiany zróżnicowania regionalnego wskaźnika poziomu rozwoju otoczenia biznesu w Polsce w latach 2000-2009

\begin{tabular}{|c|c|c|c|c|c|c|c|}
\hline \multicolumn{4}{|c|}{2000} & \multicolumn{4}{|c|}{2009} \\
\hline I & 1. & Mazowieckie & 2,15 & I & 1. & Mazowieckie & 1,99 \\
\hline \multirow[t]{4}{*}{ II } & 2. & Małopolskie & 0,58 & \multirow[t]{5}{*}{ II } & 2. & Małopolskie & 0,36 \\
\hline & 3. & Dolnośląskie & 0,55 & & 3. & Dolnośląskie & 0,34 \\
\hline & 4. & Łódzkie & 0,38 & & 4. & Pomorskie & 0,30 \\
\hline & 5. & Pomorskie & 0,33 & & 5. & Wielkopolskie & 0,22 \\
\hline \multirow[t]{6}{*}{ III } & 6. & Wielkopolskie & 0,20 & & 6. & Lubelskie & 0,11 \\
\hline & 7. & Śląskie & $-0,04$ & \multirow[t]{3}{*}{ III } & 7. & Łódzkie & $-0,05$ \\
\hline & 8. & Lubelskie & $-0,12$ & & 8. & Warmińsko-mazurskie & $-0,14$ \\
\hline & 9. & Zachodniopomorskie & $-0,24$ & & 9. & Podkarpackie & $-0,24$ \\
\hline & 10. & Kujawsko-pomorskie & $-0,32$ & \multirow[t]{7}{*}{ IV } & 10. & Podlaskie & $-0,25$ \\
\hline & 11. & Podlaskie & $-0,38$ & & 11. & Śląskie & $-0,25$ \\
\hline \multirow[t]{5}{*}{ IV } & 12. & Warmińsko-mazurskie & $-0,41$ & & 12. & Kujawsko-pomorskie & $-0,28$ \\
\hline & 13. & Podkarpackie & $-0,46$ & & 13. & Zachodniopomorskie & $-0,38$ \\
\hline & 14. & Lubuskie & $-0,49$ & & 14. & Świętokrzyskie & $-0,48$ \\
\hline & 15. & Opolskie & $-0,73$ & & 15. & Lubuskie & $-0,60$ \\
\hline & 16. & Świętokrzyskie & $-0,97$ & & 16. & Opolskie & $-0,65$ \\
\hline
\end{tabular}

Źródło: opracowanie własne

\section{ROLA OTOCZENIA BIZNESU W ROZWOJU SPOŁECZNO-GOSPODARCZYM POLSKICH REGIONÓW}

Analiza roli otoczenia biznesu w rozwoju społeczno-gospodarczym polskich regionów składa się z dwóch zasadniczych etapów. Pierwszy etap postępowania badawczego na zestawieniu klasyfikacji województw według poziomu rozwoju społeczno-gospodarczego z klasyfikacją województw według rozwoju otoczenia biznesu. W tej części analizy wykorzystano wskaźniki otoczenia biznesu uporządkowane według czterech analizowanych składników otoczenia biznesu (tabela 1) oraz wyniki wcześniej prowadzonych analiz (Churski, 
Dominiak, 2012) związanych z wydzieleniem regionów silnych i słabych gospodarczo. Wyznaczenie regionów silnych i słabych gospodarczo przeprowadzono na podstawie analizy skupień według podziału na cztery aspekty: (1) ludność i osadnictwo, (2) struktura gospodarki i rynek pracy, (3) infrastruktura techniczna i dostępność przestrzenna, (4) sytuacja finansowa i poziom zamożności (tabela 2). Skupienie (jednostek), dla którego częściej (w \%) średnie wartości cech były większe od średnich wartości w pozostałych skupieniach, zostało określone mianem regionów silnych (skupienie 3). Podobnie wyznaczone zostały skupienia regionów słabych gospodarczo (średnie wartości cech były najniższe - skupienie 2) i regionów neutralnych (skupienie 1). Dane wykorzystane do wyznaczenia regionów silnych i słabych gospodarczo dotyczą lat 2002 i 2009 i pochodzą z Banku Danych Lokalnych (GUS, www.stat.gov.pl).

Tab. 3. Wskaźniki poziomu rozwoju społeczno-gospodarczego

\begin{tabular}{|c|c|}
\hline $\begin{array}{c}\text { Aspekt rozwoju } \\
\text { społeczno-gospodarczego }\end{array}$ & Wskaźniki \\
\hline (1) aspekt społeczny & $\begin{array}{l}\text { - odsetek osób z wykształceniem wyższym (\%) } \\
\text { - współczynnik salda migracji (\%) } \\
\text { - współczynnik obciążenia demograficznego }\end{array}$ \\
\hline $\begin{array}{l}\text { (2) gospodarczy: } \\
\text { aktywność gospodarcza } \\
\text { i rynek pracy }\end{array}$ & $\begin{array}{l}\text { - stopa bezrobocia (\%) } \\
\text { - odsetek pracujących w usługach rynkowych }(\%) \\
\text { - udział usług w wdb (\%) }\end{array}$ \\
\hline $\begin{array}{l}\text { (3) infrastruktura } \\
\text { techniczna }\end{array}$ & $\begin{array}{l}\text { - wskaźnik dostępności drogowej } \sqrt{\frac{d}{p^{*} l}} \\
\text { (d-długość dróg utwardzonych, } \mathrm{p}-\text { powierzchnia, } 1 \text { - liczba ludności) } \\
\text { - wskaźnik dostępności kolejowej } \sqrt{\frac{d}{p^{*} l}} \\
\text { (d-długość linii kolejowych czynnych, } \mathrm{p} \text { - powierzchnia, } 1 \text { - liczba } \\
\text { ludności) }\end{array}$ \\
\hline $\begin{array}{l}\text { (4) sytuacja finansowa } \\
\text { i poziom zamożności }\end{array}$ & $\begin{array}{l}\text { - dochody własne budżetów gmin na jednego mieszkańca w zł } \\
\text { - dochody gospodarstw domowych do dyspozycji brutto } \\
\text { na jednego mieszkańca w zł } \\
\text { - wartość dodana brutto na jednego pracującego w zł }\end{array}$ \\
\hline
\end{tabular}

Źródło: opracowanie własne

Do regionów silnych gospodarczo w 2002 r. zaliczono cztery województwa: mazowieckie, śląskie, dolnośląskie i pomorskie. W 2009 r. uzyskano podobny rozkład województw, przy czym w zbiorze regionów silnych gospodarczo zabrakło województwa pomorskiego. Większa zgodność między rozkładami w analizowanym okresie występuje w przypadku regionów słabych gospodarczo. Zarówno w 2002 r., jak i w 2009 r. zaliczono do nich województwa: lubelskie, podkarpackie, podlaskie i świętokrzyskie. Pozostałe województwa przyporządkowano do grupy regionów neutralnych (ryc. 3). 


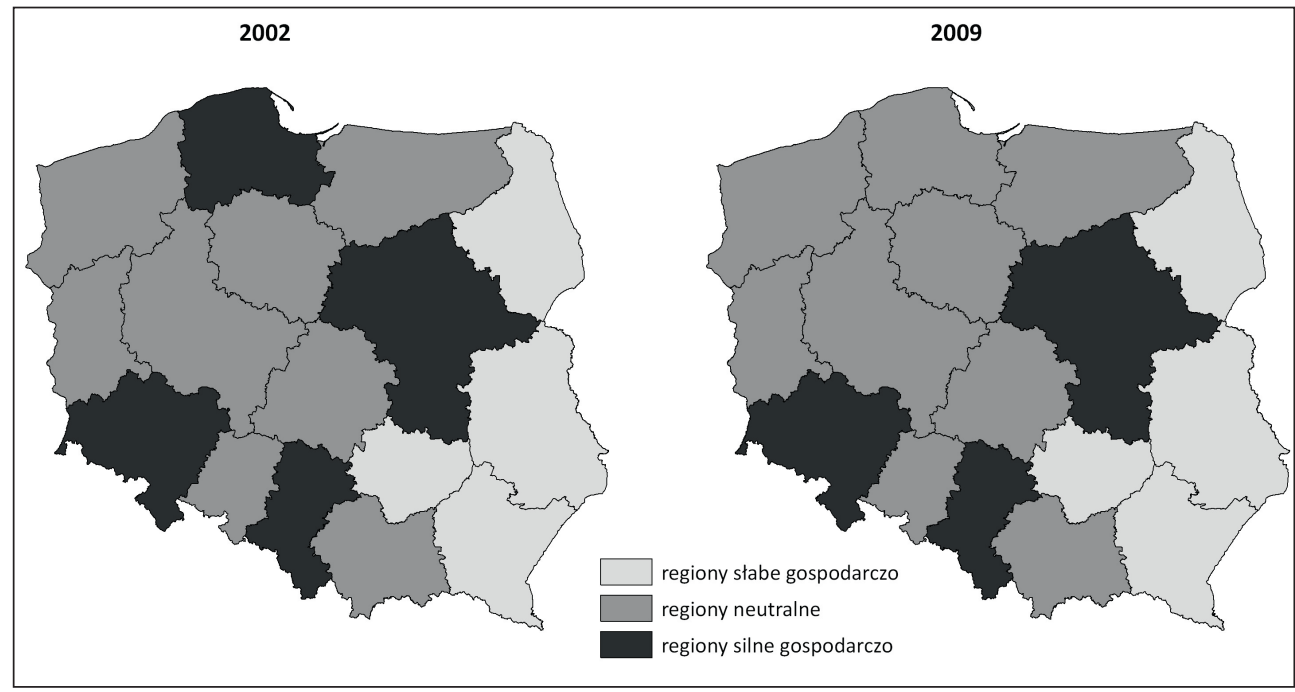

Ryc. 3. Rozkład przestrzenny regionów silnych i słabych gospodarczo

\begin{tabular}{|c|c|c|}
\hline \multicolumn{3}{|c|}{$2002 r$. } \\
\hline Skupienie 1 & Skupienie 2 & Skupienie 3 \\
\hline Kujawsko-Pomorskie & Lubelskie & Dolnośląskie \\
\hline Lubuskie & Podkarpackie & Mazowieckie \\
\hline Łódzkie & Podlaskie & Pomorskie \\
\hline Małopolskie & Świętokrzyskie & Śląskie \\
\hline Opolskie & & \\
\hline Warmińsko-Mazurskie & & \\
\hline Wielkopolskie & & \\
\hline Zachodniopomorskie & & \\
\hline \multicolumn{3}{|c|}{$2009 \mathrm{r}$} \\
\hline Skupienie 1 & Skupienie 2 & Skupienie 3 \\
\hline Kujawsko-Pomorskie & Lubelskie & Dolnośląskie \\
\hline Lubuskie & Podkarpackie & Mazowieckie \\
\hline Łódzkie & Podlaskie & Śląskie \\
\hline Małopolskie & Świętokrzyskie & \\
\hline \multicolumn{3}{|l|}{ Opolskie } \\
\hline \multicolumn{3}{|l|}{ Pomorskie } \\
\hline \multicolumn{3}{|l|}{ Warmińsko-Mazurskie } \\
\hline \multicolumn{3}{|l|}{ Wielkopolskie } \\
\hline Zachodniopomorskie & & \\
\hline
\end{tabular}

Źródło: opracowanie własne 
W drugim etapie postępowania badawczego za pomocą analizy kanonicznej przeprowadzono modelowanie zależności między poziomem rozwoju społeczno-gospodarczego (zmienne $Y_{i j}$, gdzie $i=1,2, \ldots n$, oznacza kolejne wskaźniki, a $j=1,2, \ldots n$ oznacza liczbę obserwacji, tj. regionów) a poziomem rozwoju otoczenia biznesu (zmienne $X k, j$, gdzie $k=1,2, \ldots n$, oznacza kolejne wskaźniki; $j=1,2, \ldots n$ oznacza liczbę obserwacji, tj. regionów). Rozwój społeczno-gospodarczy analizowano w ujęciu częściowym, wyróżniając cztery jego aspekty: (1) ludność i osadnictwo, (2) strukturę gospodarki i rynek pracy, (3) infrastrukturę techniczną i dostępność przestrzenną, (4) sytuację finansową i poziom zamożności. Spośród estymowanych współczynników korelacji kanonicznej wybiera się tylko pierwszy, o najwyższej wartości, odnoszący się do maksymalnej zależności między kombinacjami zmiennych $Y_{i j}$ a kombinacjami zmiennych $X k$, j. Uzyskana wartość pierwszego współczynnika korelacji kanonicznej $\mathrm{R}(\mathrm{R}>0,9)$ świadczy o silnej zależności pomiędzy poziomem rozwoju innowacyjności a poziomem rozwoju społeczno-gospodarczego w układzie województw. Zależność ta jest istotna statystycznie na poziomie $\mathrm{p}<0,05(\mathrm{p}=0,02295)$. Uzyskane wagi kanoniczne dla pierwszego współczynnika korelacji kanonicznej informujące o udziałach poszczególnych zmiennych w jego wartości pozwalają określić znaczenie każdej ze zmiennych w badanej relacji (Morrison, 1990).

Określenie zależności między poziomem rozwoju otoczenia biznesu a poziomem rozwoju społeczno-gospodarczego przeprowadzono dla danych z roku 2009, na podstawie prezentowanego zbioru wskaźników podzielonych na cztery składniki otoczenia biznesu: wyposażenie instytucjonalne, usługi dla biznesu, środowisko innowacyjne oraz klimat społeczny. Badana relacja ma charakter dwustronny. $Z$ jednej strony to otoczenie biznesu wpływa na poziom rozwoju społeczno-gospodarczego, np. przez aktywizację gospodarczą, promowanie przedsiębiorczości czy rozwój innowacji, z drugiej zaś strony to rozwój gospodarczy jest niezbędny do prawidłowego funkcjonowania instytucji i firm otoczenia biznesu.

Na podstawie wyników analizy kanonicznej stwierdza się, że w układzie regionalnym Polski zależność pomiędzy poziomem rozwoju społeczno-gospodarczego a poziomem rozwoju otoczenia biznesu jest bardzo silna. Identyfikując poziom tej zależności w ujęciu częściowym otoczenia biznesu, najsilniejsza zależność między poziomem rozwoju społeczno-gospodarczego a składnikami otoczenia biznesu odnotowano w przypadku środowiska innowacyjnego. Wartości współczynników korelacji kanonicznej kształtowały się w tym przypadku na poziomie 0,91-0,98. Szczególnie wysokie wartości współczynników występowały pomiędzy środowiskiem innowacyjnym a sytuacją finansową i poziomem zamożności oraz aspektem społecznym. Zależność ta jest obustronna, środowisko innowacyjne przyczynia się do poprawy sytuacji finansowej regionów, ale jednocześnie do rozwoju dobrze funkcjonującego środowiska innowacyjnego potrzebne są środki finansowe, których regiony słabe gospodarczo nie posiadają. Środowisko innowacyjne wysoko skorelowane jest także z aspektem społecznym - potwierdza to tezę o tym, że do rozwoju środowiska innowacyjnego niezbędne stają się czynniki w postaci kapitału ludzkiego - dobrze wykształconej i mobilnej kadry. Silną zależność zaobserwowano także w przypadku relacji: poziom rozwoju społeczno-gospodarczego - usługi dla biznesu. Wartości współczynnika korelacji wynosiły w tym przypadku dla wszystkich elementów rozwoju 
społeczno-gospodarczego (poza infrastrukturą) 0,97. Usługi dla biznesu lokalizowane są głównie w wielkich miastach, w których najłatwiej znaleźć wykwalifikowaną kadrę. Jako komercyjne firmy usługowe dające zatrudnienie znacznej części pracujących oraz dostarczające znacznego udziału WDB są także silnie skorelowane z aspektem gospodarczym, rynkiem pracy i sytuacją finansową. Stosunkowo wysokie wartości współczynnika korelacji z poziomem rozwoju społeczno-gospodarczego odnotowano także w przypadku klimatu społecznego (powyżej 0,8). Najsilniej związany jest on z aspektem społecznym rozwoju oraz z gospodarką i rynkiem pracy. Najsłabszy związek stwierdzono w przypadku relacji poziom rozwoju społeczno-gospodarczego - wyposażenie instytucjonalne. W tej sytuacji wartości współczynnika korelacji mieściły się w granicach: 0,59-0,85. Szczególnie niską siłę związku odnotowano w relacji wyposażenie instytucjonalne - infrastruktura techniczna.

Tab. 4. Wyniki analizy kanonicznej

\begin{tabular}{|l|c|c|c|c|}
\hline \multirow{2}{*}{$\begin{array}{c}\text { Składniki otoczenia } \\
\text { biznesu }\end{array}$} & \multicolumn{4}{|c|}{ Wartości współczynników korelacji kanonicznych } \\
\cline { 2 - 5 } & $\begin{array}{c}\text { Aspekt } \\
\text { społeczny }\end{array}$ & $\begin{array}{c}\text { Gospodarka } \\
\text { i rynek pracy }\end{array}$ & $\begin{array}{c}\text { Infrastruktura } \\
\text { techniczna }\end{array}$ & $\begin{array}{c}\text { Sytuacja finansowa } \\
\text { i poziom zamożności }\end{array}$ \\
\hline $\begin{array}{l}\text { Wyposażenie } \\
\text { instytucjonalne }\end{array}$ & 0,76 & 0,74 & 0,59 & 0,85 \\
\hline Usługi dla biznesu & 0,97 & 0,97 & 0,78 & 0,97 \\
\hline $\begin{array}{l}\text { Środowisko } \\
\text { innowacyjne }\end{array}$ & 0,98 & 0,94 & 0,91 & 0,98 \\
\hline Klimat społeczny & 0,87 & 0,87 & 0,85 & 0,81 \\
\hline
\end{tabular}

Źródło: opracowanie własne

\section{Podsumowanie}

Przeprowadzona analiza zależności pomiędzy poziomem rozwoju społeczno-gospodarczego a poziomem rozwoju otoczenia biznesu prowadzi do następujących wniosków. Rozkład przestrzenny województw według poziomu rozwoju społeczno-gospodarczego w dużej mierze pokrywa się z rozkładem na podstawie wskaźnika sumarycznego poziomu rozwoju otoczenia biznesu (Perkala). W ujęciu składników otoczenia biznesu największym stopniem dopasowania cechowały się: usługi dla biznesu oraz środowisko innowacyjne. Te dwa składniki otoczenia biznesu wydają się najsilniej powiązane z poziomem rozwoju społeczno-gospodarczego. Analiza zróżnicowania regionalnego poziomu rozwoju otoczenia biznesu wskazuje na znaczną przewagę województwa mazowieckiego nad pozostałymi województwami. Szczegółowa analiza jednego ze składników otoczenia biznesu - usług dla biznesu, na poziomie NUT4 wykazała, że nie dotyczy to całego województwa, a jedynie miasta stołecznego Warszawy.

$\mathrm{W}$ ujęciu dynamicznym zaznacza się tendencja do wyrównywania różnic $\mathrm{w}$ poziomie rozwoju otoczenia biznesu, przede wszystkim między województwami o przeciętnym 
poziomie rozwoju otoczenia biznesu. Obserwuje się także wzrost wartości sumarycznego wskaźnika Perkala dla wszystkich województw z klasy charakteryzującej się najsłabszym poziomem rozwoju otoczenia biznesu.

W analizie kanonicznej dowiedziono, że istnieje silna zależność pomiędzy poziomem rozwoju otoczenia biznesu a poziomem rozwoju społeczno-gospodarczego zarówno w ujęciu całościowym (wszystkie analizowane aspekty), jak i w większości przypadków w ujęciu częściowym. Najsłabszą korelację odnotowano w przypadku wyposażenia instytucjonalnego (ze względu na fakt lokowania tego typu instytucji najczęściej na terenach charakteryzujących się słabym wzrostem gospodarczym), najsilniejszą zaś w przypadku środowiska innowacyjnego. W ujęciu częściowym - szczególnie wysokie wartości współczynników występowały pomiędzy środowiskiem innowacyjnym a sytuacją finansową i poziomem zamożności oraz aspektem społecznym, co potwierdza hipotezę o rosnącym znaczeniu kapitału ludzkiego w kształtowaniu środowiska innowacyjnego. Można to również rozpatrywać z przeciwnej perspektywy, jako rolę środowiska innowacyjnego w kreowaniu wysoko kwalifikowanych kadr (proces wspólnego uczenia się). Wykazana na podstawie analizy kanonicznej siła związku między środowiskiem innowacyjności a sytuacją finansową i poziomem zamożności wskazuje z jednej strony na kosztochłonność procesu kształtowania i rozwoju innowacji, z drugiej zaś na jej wpływ na sytuację finansową i wzrost zamożności.

\section{Literatura}

Aydalot, P., Keeble, D. (1988). High Technology Industry and Innovative Environments: The European Expierence. London: Routledge.

Bailley, A. Maillat, D., Coffey, W.J. (1987). Service Activities and Regional Development: Some European Examples. Environment and Planning, A 19, 653-668.

Bernardy, M. (1999). Reactive and Proactive Local Territory: Co-operation and Community in Grenoble. Regional Studies, 33(4), 343-352.

Chojnicki, Z. (1993). Postmodernistyczne zmiany globalnego porządku społeczno-gospodarczego. Studia Regionalne i Lokalne, 12(45), 166-204.

Chojnicki, Z. (1999). Uwarunkowania rozwoju regionu nadgranicznego. Koncepcje i założenia teoretyczne. W: Z. Chojnicki (red.), Podstawy metodologiczne i teoretyczne geografii. Poznań: Bogucki Wydawnictwo Naukowe, 355-380.

Chmielewski, R., Stryjakiewicz, T., Twardowska, J., Waloszczyk, J. (2001). Innowacyjność przemysłu i jej zróżnicowanie w nowym układzie wojewódzkim. Biuletyn KPZK PAN, T. Czyż (red.), Zróżnicowanie społeczno-gospodarcze w nowym układzie terytorialnym, 197, 59-102.

Churski, P., Dominiak, J. (2012). Rola innowacji w kształtowaniu regionów rozwoju i stagnacji gospodarczej w Polsce. Studia Regionalne i Lokalne, 4, 54-77.

Coffey, W.J., Polese M. (1989). Producer Services and Regional Development: Policy Oriented Perspective. Papers of the Regional Science Association, 67, $13-27$.

Czyż, T., (1998). Transformacja społeczno-gospodarcza województwa gorzowskiego. W: J.J. Parysek, B. Gruchman (red.), Uwarunkowania i kierunki rozwoju społeczno-gospodarczego, T. 2: Studia rozwoju i zagospodarowania przestrzennego. Poznań: Akademia Ekonomiczna w Poznaniu, 334-390.

Daszkowska, M. (1998). Ustugi. Produkcja, rynek, marketing. Warszawa: Wydawnictwo Naukowe PWN. 
Domański, B., Guzik, R., Gwosdz, K. (2000). Konkurencyjność i ranga wielkich miast Polski w świetle inwestycji zagranicznych firm produkcyjnych. Biuletyn KPZK PAN, R. Domański (red.), Nowe problemy rozwoju wielkich miast i regionów, 192, 99-124.

Domański, R. (2000a). Regionalny poziom gospodarki uczącej się. Czasopismo Geograficzne, 71(3-4).

Domański, R. (2000b). Miasto innowacyjne. Studia KPZK PAN, 109.

Dominiak, J. (2004). Otoczenie biznesu jako czynnik rozwoju społeczno-gospodarczego. Przeglad Geograficzny, 76(2), 209-234.

Dominiak, J. (2006). Struktura i organizacja przestrzenna otoczenia biznesu w aglomeracji poznańskiej. Poznań: Bogucki Wydawnictwo Naukowe.

Gierszewska, G., Romanowska, M., (1997). Analiza strategiczna przedsiębiorstwa. Warszawa: PWE, $109-111$.

Gillis, W.R. (1987). Can Service Producing Industries Provide a Catalyst for Regional Economic Growth. Economic Development Quarterly, 1, 249-256.

Hand, D. , Mannila, H., Smyth, P. (2005). Eksploracja danych. Warszawa: Wydawnictwo Naukowo-Techniczne.

Hessels, M. (1994). Business Services in the Randstad Holland: Decentralization and Policy Implications. Tijdrschrift voor Economische en Sociale Geografie, 85(4), 371-378.

Hausner, J., Kudłacz, T., Szlachta, J. (1997). Instytucjonalne przesłanki regionalnego rozwoju Polski, Studia KPZK PAN, 106.

Illeris, S. (1989). Services and Regions in Europe. Aldershot: Avebury.

Jewtuchowicz, A. (1996). Powstawanie środowiska i sieci innowacji. Teorie i rzeczywistość. W: K.B. Matusiak, K. Zasiadły, T. Broczkowski, M. Pietraszewski (red.), Ośrodki innowacji i przedsiębiorczości w Polsce. Poznań: Stowarzyszenie Organizatorów Ośrodków Innowacji i Przedsiębiorczości, 59-74.

Kaluizhnova, N., Osipov, M. (2012). Institutional Factors of Innovation-oriented Regional Development. Prace Komisji Geografii Przemystu Polskiego Towarzystwa Geograficznego, 19, 116-125.

Keeble, D., Lawson, C., Moore, B., Wilkinson, F. (1999). Collective Learning Processes, Networking and Institutional Thickness in Cambridge Region. Regional Studies, 33(4), 319-332.

Keeble, D., Wilkinson, F. (1999). Collective Learning and Knowledge Development in the Evolution of Regional Clusters of High Technology SME's in Europe. Regional Studies, 33(4), 295-303.

Longhi, C. (1999). Networks, Collective Learning and Technology Development in Innovative High Technology Regions: The Case of Sophia-Antipoli. Regional Studies, 33(4), 333-342.

Martinelli, F. (1991). Producer Services' Location and Regional Development. W: F. Moulaert, P.W. Daniels (ed.), The Changing Geography of Advanced Producer Services. London: Belhaven Press, 15-29.

Matusiak, K.B. (1999). Infrastruktura przedsiębiorczości i transferu technologii w Polsce. W: J. Targalski (red.), Przedsiębiorczość a lokalny i regionalny rozwój gospodarczy. Kraków: Wydawnictwo AE.

Matusiak, K.B., Zasiadły, K. (2001). Stan, zasoby i kierunki rozwoju ośrodków innowacyjnych i przedsiębiorczości na początku 2001 r. W: K.B. Matusiak (red.), Ośrodki innowacji i przedsiębiorczości. Poznań-Łódź: Katedra Ekonomii Uniwersytetu Łódzkiego.

Mertl, J., Stawasz, E. (1996). Uwarunkowania i możliwości transferu technologii do małych i średnich przedsiębiorstw za pośrednictwem inkubatora przedsiębiorczości. W: K.B. Matusiak, K. Zasiadły, T. Broczkowski, M. Pietraszewski (red.), Ośrodki innowacji i przedsiębiorczości w Polsce. Poznań: Stowarzyszenie Organizatorów Ośrodków Innowacji i Przedsiębiorczości, 103-144.

Morrison, D.F. (1990). Wielowymiarowa analiza statystyczna. Warszawa: Państwowe Wydawnictwo Naukowe.

Nowakowska, A., Feltynowski, M. (2009). Metoda oceny potencjału innowacyjnego regionów. W: A. Nowakowska (red.), Zdolności innowacyjne polskich regionów. Łódź: Wydawnictwo Uniwersytetu Łódzkiego, Wydawnictwo Biblioteka Mateusz Poradecki. 
Nowosielska, E. (2000). Sektor usług w aglomeracji warszawskiej 1992-1997: przemiany strukturalne i tendencje rozwoju, Dokumentacja Geograficzna, 17.

Obłój, K. (1998). Strategia organizacji. W poszukiwaniu trwałej przewagi konkurencyjnej. Warszawa: PWE, 106-123.

O'Farrell, P.N., Hitchens, D.M. (1990). Producer Services and Regional Development: a Review of Some Major Conceptual Policy and Research Issues. Environment and Planning, A 22, 11411154

Parysek, J.J. (1997). Podstawy gospodarki lokalnej. Poznań: Wydawnictwo Naukowe UAM.

Pedersen P.O. (1986). The Role of Business Services in Regional Development - a New Growth Center Strategy. Scandinavian Housing and Planning Research, 3, 167-182.

Penc-Pietrzak, I. (2002). Analiza otoczenia firmy. Ekonomika i Organizacja Przedsiębiorstwa, 11.

Perry, M. (1991). The Capacity of Producer Services to Generate Growth: Some Evidence from Peripheral Metropolitan Economy. Environment and Planning, A 23, 1331-1347.

Pietrzyk, I. (2001). Polityka regionalna Unii Europejskiej i regiony w państwach członkowskich. Warszawa: Wydawnictwo Naukowe PWN.

Prawelska-Skrzypek, G., Domański, B. (1996). Lokalne i regionalne czynniki rozwoju przedsiębiorczości w świetle doświadczén polskich i zagranicznych, Kraków: Wydawnictwo AE.

Przybylska, K. 2001. Determinanty zagranicznych inwestycji bezpośrednich w teorii ekonomicznej. Kraków: Wydawnictwo AE.

Runge, J. (2007). Metody badań w geografii społeczno-ekonomicznej - elementy metodologii, wybrane narzędzia badawcze. Katowice: Wydawnictwo Uniwersytetu Śląskiego.

Słodowa-Hełpa, M. (1998). Wpływ otoczenia biznesu na rozwój społeczno-gospodarczy województwa gorzowskiego. W: J.J. Parysek, B. Gruchman (red.), Uwarunkowania i kierunki rozwoju społeczno-gospodarczego województwa gorzowskiego. T. 3. Koncepcje rozwoju. Poznań: Akademia Ekonomiczna w Poznaniu, 295-325.

Stryjakiewicz, T. (1999). Adaptacja przestrzenna przemystu $w$ Polsce $w$ warunkach transformacji. Poznań: Wydawnictwo Naukowe UAM.

Werwicki, A. (1998). Zmiany paradygmatu geografii usług. Przegląd Geograficzny, 70 (3-4).

Wolfe, D.A., Gertler, M.S. (2001). Globalisation and Economic Restructuring in Ontario: From Industrial Heartland to Learning Regions? European Planning Studies, 9 (5).

Woodward, R. (1999). Otoczenie instytucjonalne matych i średnich przedsiębiorstw. Warszawa: Centrum Analiz Społeczno-Ekonomicznych CASE.

Yoke-Tong Chew, Wai-Chung Yeung H. (2001). The SME Advantage: Adding Local Touch to Foreign Transnational Corporations in Singapore. Regional Studies, 35(5), 431-448.

Joanna Dominiak, dr, Uniwersytet im. A. Mickiewicza w Poznaniu, Instytut Geografii Społeczno-Ekonomicznej i Gospodarki Przestrzennej.

Adiunkt w zakładzie Analizy Regionalnej Instytutu Geografii Społeczno-Ekonomicznej i Gospodarki Przestrzennej Uniwersytetu im. Adama Mickiewicza w Poznaniu. Jej zainteresowania naukowe koncentrują się wokół roli innowacyjności w kształtowaniu gospodarki opartej na wiedzy, wpływu otoczenia biznesu na rozwój regionów oraz przemian w strukturze usług.

Joanna Dominiak, PhD, Senior Lecturer in the Regional Analysis Department in the Institute of Socio-Economic Geography and Spatial Management of Adam Mickiewicz University in Poznan. Research interests focus on the role of innovation in the development of a knowledge-based economy, the impact of the business environment on regional development and the changes in the structure of services.

adres/address: Uniwersytet im. A. Mickiewicza w Poznaniu,

Instytut Geografii Społeczno-Ekonomicznej i Gospodarki Przestrzennej

ul. Dzięgielowa 27, 61-680 Poznań, Polska

e-mail: dominiak@amu.edu.pl 